\title{
RAZVOJNI PROBLEMI IN MOŽNOSTI OBČINE ŽUŽEMBERK
}

Katarina Volčini, Tina Orožen Adamič, Barbara Kuzmič, Tina Šetina*

\section{Izvleček}

Prispevek prikazuje nekatere osnovne geografske značilnosti občine Žužemberk s poudarkom na obravnavi razvojnih problemov. Predlagane so tudi nekatere razvojne možnosti, pri katerih je $v$ ospredju ekološko uravnotežena pokrajina, to je tista, ki ob gospodarski učinkovitosti v čim večji meri ohranja naravne prvine in naravne procese.

Ključne besede: Žužemberk, Suha krajina, podeželje, razvojni problemi.

\section{DEVELOPMENTPROBLEMS AND POSSIBILITIES OF ŽUŽEMBERK MUNICIPALITY}

\begin{abstract}
The article presents some basic gographical features of the Žužemberk municipality, with special emphasis on problems of development. Suggested are also some development possibilities, with emphasis on ecological balanced landscape; that is the economically successful country, which reserves, in the highest possible way, all natural processes and elements.
\end{abstract}

Key words: Žužemberk, Suha krajina, rural area, problems of development.

\footnotetext{
* Študentke 4. letnika geografije, Oddelek za geografijo, Filozofska fakulteta, Univerza v Ljubljani, Aškerčeva 2, SI 1000 Ljublana, Slovenija.
} 


\section{Uvod}

Podeželje je vsak del pokrajine, kjer prevladujejo vasi in podeželska mesta, njive, travniki, pašniki, gozdovi, hoste in vode. Danes pojmujemo podeželje mnogo širše, saj prevzema mnoge funkcije pomembne za celotno družbo. Tako se podoba in notranja struktura podeželja spreminjata; na eni strani se veča število delovnih mest izven kmetijstva, locira se industrija in koncentrira poselitev, na druga strani pa poteka praznenje podeželskega prostora, opuščanje obdelovalnih manj kvalitetnih kmetijskih zemljišč in njihovo zaraščanje, drobljenje in pozidava nižinskih površin (Barbič, 1991, 47).

Podobni razvojni procesi se odvijajo tudi v občini Žužemberk, ki je v celoti podeželskega značaja. $V$ grobem lahko rečemo, da $v$ občini sledimo bipolarnemu razvoju. Na eni strani je vitalno območje doline Krke, kjer število prebivalstva narašča in se gospodarske dejavnosti koncentrirajo, na drugi strani pa je zaledje doline, ki odmira skoraj pred našimi očmi: kmetijske obdelovalne površine se opuščajo in zaraščajo z gozdom, prebivalstvo se stara in njihovo število se zmanjšuje. Zato je potrebno razvoju podeželja in njegovi problematiki nameniti še več pozornosti kot do sedaj.

Namen prispevka je prikazati osnovne fizično in družbenogeografske poteze, opozoriti na razvojne probleme in predlagati smernice bodočega razvoja podeželja v občini Žužemberk.

\section{Geografska lega in položaj občine}

Občina Žužemberk leži na vzhodu Suhe krajine, ki je ena najredkeje poseljenih slovenskih pokrajin. Obsega dolino Krke in zakraseli planotasti svet na obeh straneh doline. Nahaja se ob križišču cest Ljubljana - Ivančna Gorica Novo mesto ter Trebnje - Dvor - Kočevje. Od Ljubljane jo loči 50 km, od Novega mesta pa $25 \mathrm{~km}$. Meji s sedmimi občinami, njena površina pa je 164,3 km². Najpomembnejši kraj je Žužemberk, ki je hkrati upravno središče občine. Severozahodni del občine je v bližini Ivančne Gorice, ki se močno navezuje na Ljubljano. Z druge strani pa je močna gravitacija proti Novemu mestu in na jugu občine proti Kočevju. 


\section{Fizičnogeografske poteze}

Suho krajino v grobem lahko opredelimo kot razmeroma uravnano, v drobnem pa precej razčlenjeno in močno zakraselo pokrajino $v$ nadmorskih višinah med 300 in $600 \mathrm{~m}$. Glavne pokrajinske značilnosti so: odprtost prostora, razpršena poselitev, odmaknjenost od večjih središč, pomanjkanje površinskih vodotokov, plitva prst in obilica kamenja na površju.

Kamninska podlaga je v glavnem iz skladov apnenca in dolomita triasne, jurske in kredne starosti. Blizu Hinj je eocenski otok fliša, ki se jasno loči od kraške okolice, na stiku le-tega z apnencem pa se je razvil kontaktni kras. Območje je močno pretrto s številnimi prelomi, od katerih sta najpomembnejša Dobrepoljski in Žužemberški. Prsti na apnencih so neenake debeline, precej plitve, z izjemo prsti na dnu vrtač in kraških polj, kjer so globoke tudi več metrov. Prevladujejo rjave pokarbonatne prsti, ki so sicer debelejše, vendar precej ilovnate, izprane, težke in slabše rodovitne. Omenjeni naravni pogoji so že $v$ preteklosti narekovali težave $v$ oskrbi z vodo.

Ves vodni tok se je prestavil v kraško podzemlje. Edini površinsko tekoči vodni tok je reka Krka, ki je vrezala svojo dolino $v$ tektonski prelomnici $v$ dinarski smeri. Ostanki pliocenskega porečja Krke so številne suhe doline oziroma kraški doli. Ploske ravnice $v$ njih so se oblikovale $v$ nekdanji višini talne vode, po poglobitvi Krke pa so postopno zakrasele in razpadle $v$ posamezne kraške kotliče, vrtače in druge kraške oblike. Krka danes slovi kot edina slovenska kraška reka, ki tvori lehnjakove pragove. Tu pravijo lehnjaku lahki kamen ali lahkovec. Več lehnjaka je tam, kjer se rečna voda meša s pritoki ali izviri z dolomitnih predelov.

Po Gamsovi klimatski klasifikaciji spada Suha krajina v posebno enoto podnebja Osrednje Slovenije, kjer pade 1200 - $1350 \mathrm{~mm}$ padavin na leto, s primarnim viškom poleti. Izraženi so trije višinski pasovi: dna dolin oziroma kraških depresij, termalni in hribski pas. Kraške depresije so območja pogostih toplotnih inverzij (Rus, 1977).

Gozd prekriva precejšnje površine, njegova gospodarska vrednost pa je razmeroma majhna.V nižjih legah prevladujeta gaber in cer z gradnom, nekako nad 450 metrov n.m. pa bukev (Lovrenčak, 1984). Gozdovi se širijo na opuščene obdelovalne površine, kjer se pojavljajo predvsem leska, gaber, hrast in breza, tak gozd pa je neprimeren za gospodarsko izrabo. 


\section{Razvojni problemi}

Shema 1: Dejavniki razvoja v občini Žužemberk.

Tab.: Development possibilities in Žužemberk municipality.

\begin{tabular}{|c|c|c|c|}
\hline MOČ & ŠIBKOST & PRILOŽNOST & NEVARNOST \\
\hline $\begin{array}{l}\text { - geografska lega } \\
\text { - neokrnjena } \\
\text { narava } \\
\text { - privlačna } \\
\text { podeželska } \\
\text { pokrajina } \\
\text { - bogata naravna } \\
\text { in kulturna } \\
\text { dediščina }\end{array}$ & 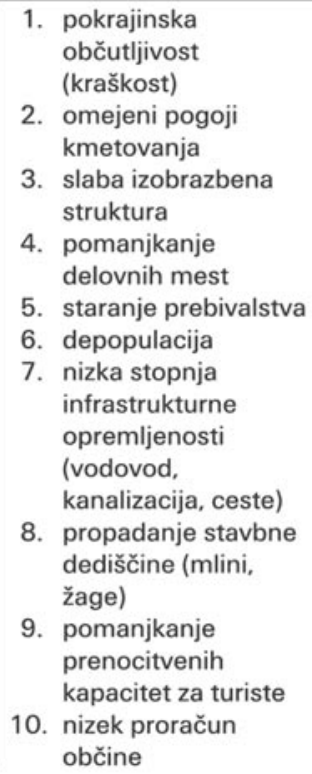 & $\begin{array}{l}\text { 11. privlačna pokrajina } \\
\text { 12. } \begin{array}{l}\text { razvoj okolju } \\
\text { prijaznega turizma }\end{array} \\
\text { 13. možnosti za } \\
\text { rekreacijo in prosti } \\
\text { čas } \\
\text { 14. obujanje starih obrti } \\
\text { (mlinarstvo, } \\
\text { žagarstvo, } \\
\text { kovaštvo) } \\
\text { 15. vikendaštvo } \\
\text { 16. dopolnilne dejavnosti } \\
\text { kmetijstva (kmečki } \\
\text { turizem, prodaja } \\
\text { pridelkov) }\end{array}$ & $\begin{array}{l}\text { 17. neenakomeren } \\
\text { gospodarski razvo. } \\
\text { (koncentracija } \\
\text { dejavnosti v dolini } \\
\text { reke Krke) } \\
\text { 18. } \\
\text { nadaljnje staranje } \\
\text { preb. (zlasti v } \\
\text { zaledju) } \\
\text { - opuščanje } \\
\text { obdelovalnih } \\
\text { površin, širjenje } \\
\text { gozda } \\
\text { - nekontrolirani } \\
\text { vodni } \\
\text { turizem na Krki }\end{array}$ \\
\hline
\end{tabular}

Važnejši dejavniki razvoja v občini Žužemberk, ki pa še niso dovolj izkoriščeni, so geografska lega $v$ osrčju Dolenjske in neposredna bližina večjih zaposlitvenih središč Ljubljane in Novega mesta. Neokrnjena narava ter podeželski značaj pokrajine dajeta idilično podobo in s tem veliko doživljajsko vrednost prostora, primernega za razvoj turizma. Bogata naravna in kulturna dediščina pa je osnovno izhodišče za trženje v turizmu.

Vse te pozitivne danosti pa omejuje mnogo zaviralnih dejavnikov (šibkost). Velika pokrajinska občutljivost zaradi kraškega značaja pokrajine omejuje razvoj intenzivnega kmetijstva, saj ne dovoljuje pretirane rabe umetnih gnojil ter pesticidov, ovira pa tudi kakršnokoli drugo intenzivno rabo tal, npr. masovni turizem ali razvoj večje industrije. Kmetijstvo dodatno ovirata še posestna razdrobljenost in razgibani relief, ki onemogočata strojno obdelavo in neugodna starostna struktura kmečkega prebivalstva. Delež kmetov pa je kljub slabim danostim precej nad slovenskim povprečjem, $26 \%$ (Zaposleni po občinah 2000). Večina kmetij je mešanih. Število kmetij 
upada, večje kmetije pa se večajo. Povprečna velikost kmetije je 13 ha, od tega je 5,5 ha kmetijske zemlje, približno toliko gozda, ostalo pa so površine v zaraščanju. Govedoreja je glavna in najbolj tržno usmerjena kmetijska dejavnost v Suhi krajini. Stara živalska vrsta so tudi ovce, ki so po vojni praktično povsem izginile, zadnjih 20 let pa se ovčereja ponovno širi. Konjereja in prašičereja sta razmeroma mladi panogi, svoj vzpon pa sta dosegli okrog 2. svetovne vojne (Gliha, 1997).

V obdobju 1900 - 2000 se je delež gozda in travnikov zaradi deagrarizacije stalno povečeval, medtem ko so se površine njiv, vrtov, sadovnjakov, vinogradov in pašnikov stalno zmanjševale. Vse to kaže na vedno bolj ekstenzivno rabo tal, kar se $v$ pokrajini kaže $v$ zaraščanju travnikov in pašnikov $z$ gozdom, njive pa se spreminjajo $v$ travnike.

Obremenjevanje okolja je že dandanes precejšnje kljub razpršeni poselitvi, saj občina nima zgrajene kanalizacije, odpadne vode pa se stekajo $v$ greznice. V občini je zgrajen le majhen krak kanalizacijskega kanala (manj kot 100 m) v ožjem središču naselja Žužemberk, ki pa ni zaključen s čistilno napravo. Čistilna naprava je zgrajena, vendar obratuje le za objekte nekdanje Iskre in je v privatni lasti (Kostevc, 2001).

Kar 22 \% prebivalcev občine ni priključenih na vodovodni sistem, kar je zelo velik delež glede na ostale slovenske občine. Brez oskrbe z vodo iz vodovodnega sistema je skoraj celotno območje levo od reke Krke, zlasti Ajdovska planota ter nekateri manjši zaselki ali deli naselij, kjer se prebivalci še vedno oskrbujejo z vodo iz kapnic. Vendar pa tudi preostalih $88 \%$ prebivalcev občine ni dosti na boljšem, saj so odvisni od neoporečnosti vodnega vira v Globočcu (pri Zagradcu), ki pa je nemalokrat dvomljive. Razmere so bile najbolj očitne jeseni 1998, ko je bil Globočec onesnažen zaradi izlitja nafte v Ortneku pri Ribnici, zaradi česar ni imel primerne preskrbe z vodo iz javnega vodovoda noben prebivalec občine Žužemberk, vodo pa so jim dovažali s cisternami. Precejšen del vodovodnega omrežja je iz azbestno cementnih in polietilenskih cevi, na katerih so pogoste okvare. Te vodovode so v Suhi krajini začele graditi mladinske delovne brigade ob koncu 70. let. Kljub vsemu temu pa iz proračuna 2001 ne bo sofinanciran noben projekt gradnje vodovoda ali kanalizacije (Lindič Dragaš, 2001).V načrtu je izgradnja dveh vodovodov, ki se bosta napajala iz vrtin v Križah in na Vinkovem Vrhu. Leta 1994 je bila pod naseljem Gornji Križ izvrtana 200 m globoka vrtina, iz katere bo možno črpati $5 \mathrm{l} / \mathrm{s}$ vode, s katero bodo oskrbovali naselja Gornji in Dolnji Križ, Vrhovo pri Žužemberku in Vrh pri Križu. Vrtina pri 
Vinkovem Vrhu pa je globoka $300 \mathrm{~m}$ in ima izdatnost $10 \mathrm{l} / \mathrm{s}$ vode. Napajala bo območje Ajdovske planote, presežek vode pa bodo lahko odvajali v vodooskrbni sistem Dvor. Upajo, da bo količina vode zadoščala za oskrbo večine občine in da kmalu ne bodo več odvisni od vodnih virov iz drugih območij.

Cestno omrežje je znotraj občine dobro razvito, saj je zaledje doline Krke povezano z relativno novimi cestami. Širše gledano pa je območje občine slabše dostopno in odmaknjeno od glavnih prometnih tokov, kar ovira celovit razvoj občine. Iz Ljubljane je dostopno po avtocesti, s katere se pri Ivančni Gorici odcepi regionalna cesta I. reda, ki vodi naprej proti Novemu mestu. Poteka po dolini Krke in predstavlja glavno prometno os skozi občino. Na odseku med Zagradcem in Dvorom je zelo ovinkasta, ozka in v slabem stanju. Potrebna je čimprejšnje rekonstrukcije, ki bi bistveno povečala promet skozi občino. Iz smeri Kočevja je kvalitetna regionalna cesta I. reda, ki vodi vse do Dvora. Južni del občine zato gravitira proti Kočevju. Dostop do občine je možen še iz Trebnjega po asfaltirani cesti preko Dobrniča do Žužemberka. Med najpomembnejše lokalne ceste v občini Žužemberk sodi lokalna cesta Zagorica - Volčja jama - Žužemberk. Ta cestna povezava je za širše območje (tudi Belo krajino) najbližja prometna pot do priključka na avtocesto Ljubljana - Zagreb. Modernizacije omenjene lokalne ceste na odseku Reber - Replje je zato bistvenega pomena za razvoj Suhe krajine in s tem tudi občine Žužemberk (Kostevc, 2001).

Demografska slika občine je neugodna, saj je kar 37 naselij (od skupno 51 naselij v občini) demografsko ogroženih. Dvajseto stoletje je bilo namreč obdobje izseljevanja in vsesplošnega upada števila prebivalstva. Po propadu železarstva in s speljavo železnice mimo doline Krke na začetku 20. stoletja se je začela gospodarska kriza. Izseljevanje je bilo zato najmočnejše od leta 1890 do 1 . svetovne vojne in je bilo predvsem odraz gospodarske krize in agrarne prenaseljenosti. Druga svetovna vojna je dodatno prizadela prebivalstvo, kar je še pospešilo izseljevanje. Skupno število prebivalcev občine se je v zadnjih 120 letih skorajda prepolovilo, in sicer s 7407 leta 1880 na samo 4677 prebivalcev leta 2000. Vsa naselja v občini, razen Žužemberka, Dvora in Sadinje vasi, izkazujejo močan in stalen upad števila prebivalcev vse od začetka 20 stoletja do danes. Proces depopulacije še ni ustavljen. V prometno dostopnejši dolini reke Krke je število prebivalcev začelo stagnirati ali celo naraščati (Žužemberk, Dvor, Sadinja vas, Gornji Kot). V zaledju reke Krke pa je stagnacija prebivalstva v zadnjih 20 letih opazna le v naseljih Lazina, Lopata, Lašče, Mali Lipovec, Veliki 
Lipovec, Doljni Ajdovec in Podlipa, drugod pa število prebivalstva naglo upada. Staranje prebivalstva je logična posledica vsesplošnega upada rodnosti in izseljevanja.

Graf 1: Gibanje števila prebivalcev v občini Žužemberk 1880-2000.

Graf 1: Population growth in Žužemberk municipality, 1880-2000.

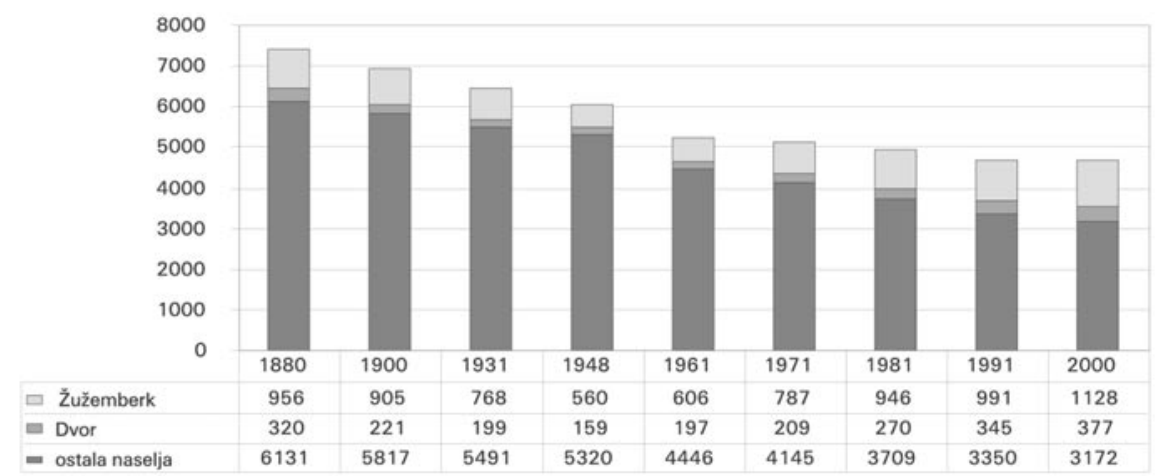

Vir/Source: Gliha, 1997, Statistični urad Republike Slovenije, stanje 30.6.2000.

Pomanjkanje delovnih mest je velika ovira za razvoj občine. V preteklosti se je zaposlovala predvsem nekvalificirana delovna sila, zato izobrazba ni igrala tako pomembne vloge. Neustrezna delovna mesta v manjših in bližnjih obratih bolje izobražene delovne sile ne zadržujejo, temveč jo silijo k dnevni migraciji ali izselitvi (Zupančič, 1988). Leta 1991 je bilo v občini 1627 zaposlenih in 98 nezaposlenih oseb. Od tega se je v naselju bivanja zaposlilo le 292 oseb, kar znaša 18 \% vseh zaposlenih. Ostalih 82 \% zaposlenih izven naselja bivanja predstavlja dnevne migrante, od katerih jih približno tretjina dela v sosednjih občinah (Popis prebivalstva 1991). Prometni položaj vpliva na migracijsko usmerjenost prebivalstva $v$ Ljubljano, Novo mesto in Kočevje.

Primarni sektor je leta 1991 še vedno zaposloval kar 27,2 \% prebivalstva občine. Največji delež zaposlenih v primarnem sektorju so izkazovala manjša naselja s slabšo prometno dostopnostjo do zaposlitvenih centrov (Popis prebivalstva 1991). Sekundarni sektor zaposluje največ prebivalcev, kar kaže na gospodarsko nerazvitost občine. Industrijska nerazvitost Suhe krajine pa je na srečo imela tudi nekaj dobrih posledic, saj je narava ostala skoraj neobremenjena $z$ industrijskimi odplakami. Edina industrijska 
Graf 2: Struktura zaposlenih po sektorjih v občini Žužemberk leta 1991.

Graf 2: Activity structure of employed persons in Žužemberk municipality,1991.

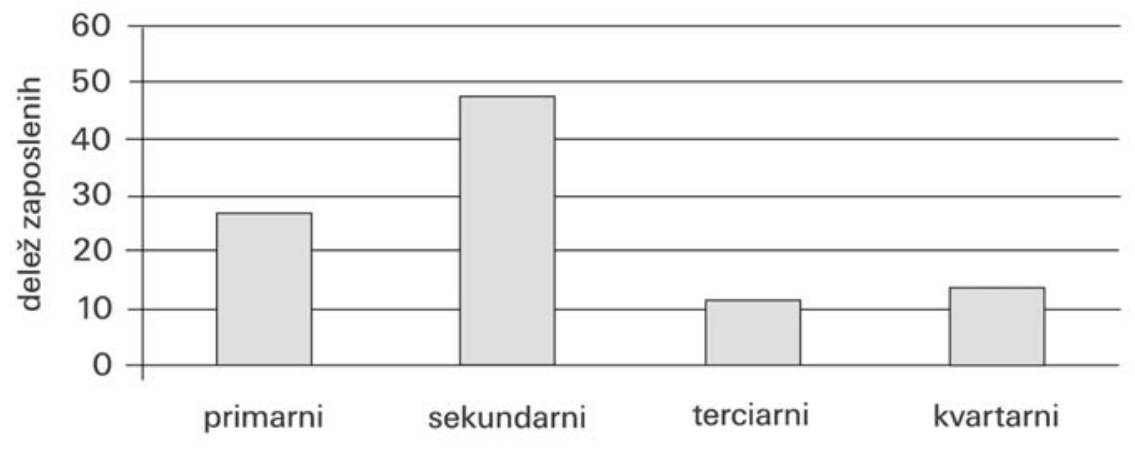

Vir/Source: Krajevni leksikon Slovenije, 1995.

obrata, ki sta se razvila v Občini Žužemberk, sta bila Iskra - tovarna keramičnih kondenzatorjev Žužemberk, ustanovljena leta 1960 (kasneje Keko) in lesnopredelovalno podjetje Novoles Dvor, ustanovljeno leta 1950 kot Ergo Dvor (Kostevc, 1997). Tovarna Iskra je šla leta 1994 v stečaj in je takrat obdržala le še okoli 50 zaposlenih, podjetje Novoles Dvor pa so prestavili v Stražo. Tako danes prevzemajo razvoj privatna podjetja: Kekon, Keko oprema, Keko Varicon, Stelem in FS, ki so vsa nastala iz tovarne Iskra. K razvoju pa prispevajo tudi GNGM, Metes, Unitplast, Install, Alboma, Ribarnica Legan in druga ter seveda KZ Suha krajina, d.o.o., Žužemberk s trgovsko in gostinsko mrežo $v$ Suhi krajini, $v$ zadnjem času tudi s svojo pekarno Grad (Kostevc, 1997). Veliko ljudi se ukvarja tudi z lesno dejavnostjo (razrez lesa, mizarstvo) in avtoprevozništvom.

Izobrazbena struktura v občini Žužemberk je bila leta 1991 izredno slaba. Največ prebivalcev je imelo le nedokončano osnovno šolo, in sicer $35,8 \%$. Dokončano osnovno šolo je imelo $32,9 \%$ prebivalcev, $27,1 \%$ srednjo, le $2,3 \%$ pa višjo oziroma visoko izobrazbo. Med tistimi s srednješolsko izobrazbo prevladujejo poklicne, tehnične in druge strokovne šole ter šole za srednje usmerjeno izobraževanje, gimnazijo pa je končalo le 20 oseb. V občini je bilo ob popisu tudi 25 nepismenih oseb ter 30 oseb brez šolske izobrazbe (Popis prebivalstva 1991). 


\section{Razvojne možnosti}

Zaostrene gospodarske razmere vse bolj silijo $v$ iskanje lastnih razvojnih možnosti, ki bi omogočile najprej preživetje lokalnega prebivalstva, v drugi fazi pa osnovanje razvojnih jeder večjih razsežnosti.

Občina ima odlične naravne in družbene potenciale za razvoj okolju prijaznega podeželskega turizma in nanj vezanih storitvenih dejavnosti. Nosilci razvoja so lahko naslednje dejavnosti: turistične kmetije, kolesarstvo, pohodništvo, jahanje, kopanje, čolnarjenje, rafting, odbojka, lokostrelstvo, obujanje starih obrti (kovaštvo, mlinarstvo, žagarstvo) itd.. Te dejavnosti so $v$ občini trenutno razvite $v$ manjši meri, turistična infrastruktura in superstruktura pa je nezadostna. Potrebno je zgraditi turistične ceste in parkirišča, kolesarske steze, rekreacijske objekte in objekte za zabavo. Prav tako primanjkuje prenočitvenih kapacitet, zato je potrebna izgradnja turističnih bivalnih objektov (turistične kmetije, apartmaji, gostišča s prenočišči, šotorišča, mladinska prenočišča itd.). Pri načrtovanju infrastrukturnih objektov so običajno zanemarjeni lokalni interesi, zanemarjajo se vplivi na okolje, ki jih povzročajo nekateri objekti in dejavnosti.

Ker je velikost kmetij za intenzivno kmetijstvo premajhna, dodatno pa obdelavo zemlje otežuje še razgiban relief, je možna usmeritev kmetij v ekološko kmetijstvo, torej v ekstenzivno rabo tal. Perspektive so v ekoloških kmetijah, vinogradništvu, sadjarstvu, čebelarstvu in živinoreji. Ekološke kmetije bi se usmerile $v$ ponudbo zdrave "eko" hrane, npr. suho sadje, domači sok in kis, domače pecivo, domači siri itd.. Rezultati ocenjevanja vin so pokazali, da je možno pridelovati kakovostna in vrhunska vina, kar bi v tem območju lahko prispevalo $h$ gospodarnejšemu kmetovanju. Prednost teh pridelkov je bistveno boljša kvaliteta in temu primerno visoka cena. Ta dejavnost pa bi predstavljala le dodatni vir zaslužka, saj trenutno na kmetijah prevladuje ostarelo prebivalstvo. Sklepamo, da bi se vsaj nekatere družine z manjših kmetij lahko preživljale, če bi bil zagotovljen čimbolj neposreden reden odkup in prodaja sezonskih pridelkov. Na travniških območjih in območjih zaraščanja pa bi bilo smiselno gojiti drobnico in govedo.

Kakovost življenja na podeželju mora temeljiti na uvajanju gospodarskih dejavnosti, ki temeljijo na lokalnih virih in dobrinah in niso v nasprotju $z$ varovanjem okolja. Razvoj podeželja bi moral temeljiti na ekoloških ukrepih (ekološka pridelava hrane, gradnja zelenih rekreacijskih površin, prenova in 
sanacija podeželskih naselij itd.), in sicer z velikim poudarkom na pomenu čistega okolja. Naselja v občini so manj razvita in zato slabo opremljena $s$ komunalno, socialno, izobraževalno in kulturno infrastrukturo.

\section{Zaključek}

Še v 19. stoletju je bila zgornja dolina Krke eno izmed gospodarsko bolj razvitih območij Slovenije. K temu je prispevalo zlasti fužinarstvo in železarstvo, razvite pa so bile tudi nekatere druge panoge, na primer žagarstvo, oglarstvo, strojarstvo in usnjarstvo. Po raznih ocenah je bilo takrat $v$ teh obratih $v$ dolini Krke zaposlenih približno 2500 ljudi. To je pomenilo visoko gospodarsko razvitost in dolino Krke bi takrat lahko označili za neagrarno pokrajino. Propad fužinarstva in zgraditev železnice mimo doline Krke ob Temenici sta dolino Krke dokončno potisnila v gospodarsko osamo. $V$ začetku 20. stoletja je tako prišlo do ponovne preusmeritve v agrarno dejavnost. Do 60. let, ko so bili v Žužemberku in Soteski zgrajeni prvi industrijski obrati, je pokrajina nazadovala in ljudje so se močno odseljevali (Perko, Orožen Adamič, 1998).

Občina Žužemberk danes spada med ekonomsko šibka območja z mnogimi strukturnimi problemi (Ur. I. RS, št. 59/00). Slab gospodarski položaj je posledica neugodnih naravnih razmer, zgodovinskih dogodkov, slabe prometne dostopnosti, oddaljenosti od večjih zaposlitvenih središč, pomanjkanja delovnih mest, pomanjkljive izobrazbe, nezadostne komunalne opremljenosti, kar se vse odraža v depopulaciji in staranju prebivalstva ter v opuščanju in zaraščanju obdelovalnih površin. Gospodarska dejavnost je omejena na ozko dolino reke Krke, skrb vzbujajoče pa je zaledje doline, ki gospodarsko in demografsko odmira. Za razvoj občine Žužemberk bi bila po našem mnenju bistvenega pomena razbremenitev doline Krke in uvajanje novih zaposlitvenih mest $v$ zaledju. Za to pa bi bilo potrebno izboljšati infrastrukturo, določiti ustrezne lokacije za razvoj dejavnosti, predvsem pa osveščati prebivalstvo o kvaliteti življenja na podeželju.

Kljub velikim razvojnim problemom pa so $v$ občini določene razvojne možnosti. Prihodnost je $v$ razvoju podeželskega turizma in ekološkega kmetijstva. Te dejavnosti lahko zadržijo prebivalstvo na podeželju, kar je bistvenega pomena za izboljšanje sedanje slabe demografske strukture prebivalstva. S tem bi zmanjšali dnevne migracije in odseljevanje. Izboljšanje kvalitete življenja prebivalcev je torej nujno, da se ustavijo neg- 
ativni demografski trendi in vzpostavi boljša starostna struktura. Z izboljšanjem cestnega omrežja in predvsem $z$ navezavo na avtocestno omrežje bi podaljšali suburbanizacijo Ljubljane, kar bi v občino privabilo nove prebivalce. Dobra dostopnost pa bi pomenila razvoj in lepšo prihodnost občine in njenih prebivalcev.

\section{DEVELOPMENT PROBLEMS AND POSSIBILITIES OF ŽUŽEMBERK MUNICIPALITY}

\section{Summary}

Still in 19th century the Upper Krka Valley was one of economicaly well developed regions of Slovenia. There was about 2500 workers employed in the manufacture activities. The railway, avoiding the Krka valley had left the valley behind the economic active areas; the prosperity of the valley ended. The population of the region had to turn back to the agriculture and many of them emigrated.

The Žužemberk municipality is characterised by economic weakness and many structural problems: bad agricultural conditions (carst area), small farms, relatively great distance from important urban centers $(50 \mathrm{~km}$ to Ljubljana, $25 \mathrm{~km}$ to Novo mesto), lack of employement possibilities, law education level, bad infrastructure etc. The result of problems mentioned above is evident: emigration of the population, more and more aged people, abandoning of cultivation. The economic activity is concentrated alog the narrow and touristicaly attractive Krka valley only. Decentralisation of economic activity should be spread on a wider part of the region to maintain still populated area.

The future of the region could be more prosperious activating local potentials, especially touristic activity and sustainable (ecological) farming. Proposed project have to be supported by municipality and central government, for example by improving the road connections with Ljubljana. 


\section{Viri in literatura}

Barbič, A., 1991: Prihodnost slovenskega podeželja. Prostor, prebivalci, gospodarske dejavnosti. Tiskarna Novo mesto, Dolenjska založba, Novo mesto, 285 strani.

Gams, I., 1974: Kras. Slovenska matica, Ljubljana.

Gliha, S., 1997: Gibanje površine kmetijskih zemljišč, števila prebivalstva in števila živine v Suhi krajin. Žužemberški grad 1997, Suhokranjski zbornik, Žužemberk, str.71-80.

Kostevc, V., 2001: Problematika vodooskrbe v občini Žužemberk, občinsko gradivo.

Lindič Dragaš, Z., 2001: Suha krajina še suha. Delo, 22.1. 2001.

Lovrenčak, F., 1984: Pedogeografske in vegetacijsko-geografske značilnosti Dolenjske, Dolenjska in Bela krajina, Prispevki za 13. zborovanje slovenskih geografov v Dolenjskih toplicah od 12.-14. oktobra 1984, Geografsko društvo Slovenije, Ljubljana, 1984, str. 146 - 166.

Perko, D., M. Orožen Adamič, 1998: SLOVENIJA Pokrajine in ljudje. Geografski inštitut ZRC SAZU, Založba Mladinska knjiga, str. 472-483 in 735.

Popis prebivalstva 1991. Statistični urad Republike Slovenije; Ljubljana, 1991.

Rus, A., 1977: Suha krajina - geografski opis. Diplomska naloga, Univerza v Ljubljani, Filozofska fakulteta, Oddelek za geografijo, Ljubljana, 96 strani.

Škufca, F., 2000: Občina Žužemberk. Žužemberški grad 2000, Suhokranjski zbornik, Žužemberk, str.20,21.

Zupančič, J., 1988: Socialnogeografska transformacija Suhe krajine. Diplomska naloga, Univerza v Ljubljani, Filozofska fakulteta, Oddelek za geografijo, Ljubljana, 103 strani. 